\title{
Adaptation and validation of a Self-Efficacy Scale for Physical Activity Practice - SESBC Scale
}

\author{
Adaptação e validação de uma Escala de Autoeficácia para a Prática de Atividade \\ Física - Escala EABEMC
}

\section{AUTHOR'S \\ Walan Robert da Silva ${ }^{1}$ (D) \\ Cínara Sacomori ${ }^{2}$ (D) \\ Thiago Emannuel Medeiros ${ }^{1}$ (D) \\ Tailine Lisboa ${ }^{1}$ (iD \\ Kamyla Thais Dias de Freitas ${ }^{1}$ (D) \\ Fernando Luiz Cardoso ${ }^{1}$ (D) \\ 1 Universidade do Estado de Santa Catarina Centro de Ciências da Saúde e do Esporte, Florianópolis, Santa Catarina, Brazil. \\ 2 Hospital del Salvador, Universidad Bernardo O'Higgins, Universidad Andres Bello, Santiago, Región Metropolitana, Chile.}

\section{CORRESPONDING}

Walan Robert da Silva

walanrobert@hotmail.com

Rua Pascoal Simone 358, Coqueiros,

Florianópolis, Santa Catarina, Brazil.

CEP: 88080-350.

\section{DOI}

10.12820/rbafs.23e0038

\section{(c) $(\$)$}

Copyright: This is an open-access article distributed under the terms of the Creative Commons Attribution License ${ }^{\circledR}$, which permits unrestricted use, distribution, and reproduction in any medium, provided that the original author and source are credited.

\begin{abstract}
The present study aimed to perform the translation, cross-cultural adaptation, and construct validation of the Self-Efficacy Scale based on the Stages of Behavior Change for Physical Activity Practice (SESBC), and also to test its internal consistency and reproducibility. The scale, composed of 20 items, was adapted to the Brazilian reality using the technique of back-translation. In empirical terms, construct validation and the internal consistency of the instrument were tested in 281 state public servant technicians of both sexes, older than 18 years, while reproducibility was tested in 91 university students. In the exploratory factor analysis, the 19 items loaded onto one single factor, and factor loadings varied from 0.41 to 0.88 , explaining $52.7 \%$ of the total variance of the subjects' responses. The SESBC showed good reliability in terms of internal consistency (alpha of 0.94) and good reproducibility in terms of test and re-test (ICC < 0.40-0.80) after two weeks. Of the 19 items, 17 presented ICC $>0.60$. Therefore, the SESBC reached adequate levels of validity, internal consistency and reproducibility and can be used to measure self-efficacy for physical activity practice.

Keywords: Physical activity; Psychometry; Attitudes; Self-efficacy.

RESUMO

O presente estudo teve como objetivo realizar a tradução, adaptação transcultural, validação de construto, consistência interna e reprodutibilidade da Escala de Autoeficácia baseada nos Estágios de Mudança de Comportamento para a Prática de Atividade Física (EABEMC). A escala composta por 20 itens foi adaptada à realidade brasileira utilizando-se da técnica de backtranslation. Em termos empíricos testou-se a validade de construto e a consistência interna do instrumento em 281 técnicos servidores públicos de ambos os sexos maiores de 18 anos, enquanto a reprodutibilidade foi verificada em 91 universitários. Na análise fatorial exploratória, os 19 itens carregaram num único fator, com as cargas fatoriais variando de 0,41 a 0,88 , explicando 52,7\% da variância total das respostas dos sujeitos. A EABEMC apresentou boa consistência interna satisfatória (alfa de 0,94) e boa reprodutibilidade (CCI <0,40-0,80), sendo que dos 19 itens 17 apresentaram CCI >0,60. A EABEMC alcançou niveis adequados de validade, consistência interna e reprodutibilidade, podendo ser utilizada para mensurar a autoeficácia para prática de atividade física.
\end{abstract}

Palavras-chave: Atividade física; Psicometria; Atitudes; Autoeficácia.

\section{Introduction}

Self-efficacy is defined as the belief or the confidence people have in their skills and abilities to perform behaviors necessary to reach a desired objective or achieve an expected outcome ${ }^{1}$. It is a construct included in different theories and models, including social learning theory, the transtheoretical model ${ }^{2}$, the health belief model $^{3}$, and the theory of planned behavior ${ }^{4}$.

Self-efficacy has been widely associated with higher levels of physical activity practice ${ }^{5}$. In view of this, scales have been developed to measure this construct in the context of physical activity ${ }^{6-9}$. However, Massê et al. ${ }^{10}$ argue that these scales focus solely on measuring people's capacity for overcoming barriers in order to be physically active.

Thus, based on the evidences found by Laffrey \& Wannipa ${ }^{11}$, who suggested a relationship between self-efficacy and the stages of the transtheoretical model of behavior change, Massê et al. ${ }^{10}$ proposed the creation of a self-efficacy scale combined with those 
stages, as a tool to measure people's belief in their efficacy to change health risk behaviors. With this scale, it is possible to identify at which behavior stage a person is in relation to physical activity practice.

The main advantage of this model is the possibility of classifying people in relation to their intention and current engagement concerning a given health-related conduct, such as regular physical activity practice. In the transtheoretical model, cognitive and behavioral processes, as well as environmental factors, are considered important and determinant of changes between stages towards the desired behavior ${ }^{2}$.

In this sense, validating and adapting the Self-Efficacy Scale based on the Stages of Behavior Change for Physical Activity Practice (SESBC) to the Brazilian context is relevant, in view of the fact that the available scales that we analyzed do not include factors like cognitive, behavioral and environmental processes. Therefore, this study aimed to perform the translation, cross-cultural adaptation and construct validation of the Self-Efficacy Scale based on the Stages of Behavior Change for Physical Activity Practice (SESBC), and also to test its internal consistency and reproducibility.

\section{Method}

The present study translated the instrument "Self-Efficacy Scale for Physical Activity" ${ }^{10}$ into Brazilian Portuguese and tested construct validity, internal consistency and reproducibility. The original instrument has 20 items and 4 subscales designed to assess self-efficacy at the following stages: contemplation (4 items), preparation (7 items), action/maintenance (5 items), and moving out of relapse (4 items), all with response options in a five-point Likert scale ( 1 = extremely confident, 2 = very confident, 3 = confident, $4=$ somewhat confident, and $5=$ not confident at all).

For the process of translation and testing of the instrument, the stages presented in Figure 1 were followed.

In the instrument adaptation process, the steps recommended by the specialized literature ${ }^{13-15}$ were followed. Initially, the SESBC was translated by two sworn translators, who provided two different versions of the scale: "T1 and T2". After this stage, a meeting was held with both translators and the main researcher to establish a consensual version in Portuguese (T3).

Version T3 was translated into English (back-translation) by a third sworn translator. This professional, whose native language is English, is fluent in Portuguese and was not familiarized with the original in-
Translation and cross-cultural adaptation

Process: Translation by 2 Brazilian sworn translators.

Product: "T1" and "T2", resulting in a version "T1 + 2".

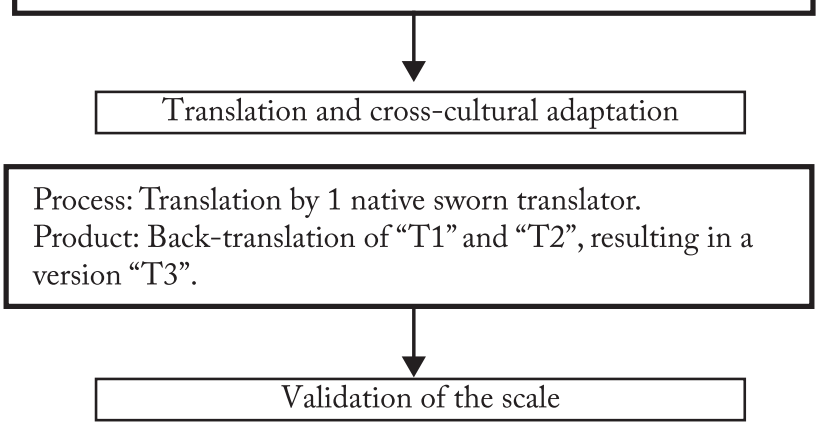

Process: Testing of the scale's clearness by 281 administrative technicians, 146 (52\%) men and 135 (48\%) women.

Validation of the scale

Process: Exploratory factor analysis with data of the 281 administrative technicians to measure the scale's construct validity.

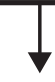

Reproducibility

Process: administration of the scale to 91 university students, 41 (45.1\%) men and 50 (54.9\%) women, at two distinct moments. Product: Back-translation of "T1" and "T2", resulting in a version "T3".

Figure 1 - Methodological steps for the translation, adaptation and validation of the $\mathrm{SESBC}^{12}$.

strument. The original version and the back-translation were compared and the researchers established a consensual version in Portuguese.

To assess construct validity and the reliability of the scale's final version, administrative technicians of both sexes were selected. All of them were older than 18 years and worked at two State Foundations in the state of Santa Catarina (Southern Brazil). The sample was selected in an intentional way, according to Pasquali's ${ }^{16}$ proposal: in validation studies, the author suggests a minimum of 10 subjects per scale item.

The scale's reproducibility was assessed in a group of participants chosen in an intentional way, composed of university students of both sexes. Replications of the scale administration were performed with an interval of 14 days. 
Descriptive statistics was used - mean, standard deviation, relative and absolute frequency - to characterize the participants. The sociodemographic characteristics, measured by means of a questionnaire, were sex and age. Construct validity was assessed through exploratory factor analysis with Varimax rotation, which identifies common components in a large number of variables. A factor loading index $<0.30$ was adopted for excluding items from the scale $^{16}$. The KMO and Bartlett's sphericity tests were used to measure the adequacy of the factor analysis. To measure internal consistency, Cronbach's alpha was employed, using the classification: very good consistency: > 0.90; good: 0.89 to 0.80 ; acceptable: 0.79 to 0.70 ; poor: 0.69 to 0.60 ; very poor: $<0.59^{17}$. Test and retest reproducibility was assessed by means of the Intraclass Correlation Coefficient (ICC), and the following classification was adopted: poor: $<0.40$; satisfactory to good: $0.40-0.74$; excellent: $>0.75^{17}$.

Data tabulation was performed with the aid of the Microsoft Excel $^{\oplus}$ program and analyzed with the Statistical Package for the Social Sciences (SPSS) ${ }^{\circledR}$ version 20.0.

The research complied with the standards required by the Declaration of Helsinki and was approved by the Ethics Committee for Research Involving Human Subjects of Universidade do Estado de Santa Catarina, protocol no. $275381 / 2013$.

\section{Results}

To assess construct validity and the reliability of the scale's final version, 281 administrative technicians from two State Foundations in Santa Catarina, 146 men (52\%) and 135 women (48\%), were selected. The mean age was 34.4 years $(s d=10.8)$. The scale's reproducibility was assessed in a group of participants composed of 91 university students - 41 men (45.1\%) and 50 women $(54.9 \%)$ - with mean age of 20.7 years ( $\mathrm{sd}=3.5$ ).

In the exploratory factor analysis, all the items of the SESBC loaded onto one single factor - unidimensional scale. The item "find a partner to be physically active" was excluded from the scale because it presented a factor loading lower than 0.30 . The final version of the instrument had 19 items with factor loadings varying from 0.41 to 0.88 and total variance equal to $52.7 \%$ (Table 1 ).

Table 2 presents the values of Cronbach's alpha (which indicates the instrument's internal consistency) for the 19 items of the adapted scale, as well as the values in case an item was removed from the scale. It was found that the internal consistency was 0.94 , being considered very good.

Table 3 shows the values referring to the test-retest reproducibility measures of the scale. The ICCs varied from 0.41 (item 1 ) to 0.80 (item 6). Of the 19 items of the scale, 17 presented ICC above 0.60 , indicating that the reproducibility of the SESBC can be considered satisfactory to excellent.

Box 1 presents the original items of the $\mathrm{SESBC}^{10}$.

Box 1 - Original items of the SESBC ${ }^{10}$.

\begin{tabular}{|l|}
\hline Item \\
\hline Be physically active (i.e., accumulate 30 min of brisk walking in 1 day) \\
Be physically active on a regular basis (be active 3 to 5 days a week) \\
Make a commitment to be physically active on a regular basis \\
Start being physically active in the next few weeks \\
Find a physical activity program that you would enjoy \\
Find a convenient place to be physically active \\
Find a safe place to be physically active \\
Find time in your busy schedule to be physically active \\
Rearrange your schedule to be physically active \\
Find ways to be physically active when the weather is bad \\
Maintain your physical activity program during the holiday season \\
Find ways to keep your physical activity program enjoyable \\
Maintain your physical activity program when your family responsibilities \\
are more demanding than usual \\
Maintain your physical activity program when your work responsibilities \\
are more demanding than usual \\
Maintain your physical activity program for another 3 months \\
Begin your physical activity program again \\
Commit to being physically active again \\
Set a regular routine to be physically active again \\
Feel comfortable being physically active again
\end{tabular}

\section{Discussion}

The adaptation and validation of an instrument to assess self-efficacy for physical activity practice in Brazilians is important in the current context due to its capacity for predicting behavior changes related to adherence to and maintenance of active behavior ${ }^{5}$. The present study translated and adapted the SESBC and also assessed the construct validity, internal consistency and reproducibility of the scale, finding adequate values to all these psychometric indicators in the investigated context.

Cross-cultural adaptation is a necessary procedure in the validation process of an instrument developed in another language and context. In the present study, the translators' collaboration at the initial stage was important for the production of the "translated versions". In addition to discussing translation limits and adaptations to Portuguese, they clarified possible utilizations 
Table 1 - Exploratory factor analysis of the self-efficacy scale for physical activity among 291 administrative technicians from two State Foundations of Santa Catarina.

\begin{tabular}{|c|c|c|}
\hline Item & SESBC Brazil & Original \\
\hline \multicolumn{3}{|l|}{ Contemplação/Contemplation } \\
\hline $\begin{array}{l}\text { Ser fisicamente ativo (por exemplo, realizar uma caminhada confortável de } 30 \text { minutos em } 1 \text { dia)/ Be physically } \\
\text { active (i.e., accumulate } 30 \text { min of brisk walking in } 1 \text { day) }\end{array}$ & 0.64 & 0.64 \\
\hline $\begin{array}{l}\text { Ser fisicamente ativo regulamente (ser ativo } 3 \text { a } 5 \text { dias por semana)/ Be physically active on a regular basis (be } \\
\text { active } 3 \text { to } 5 \text { days a week) }\end{array}$ & 0.71 & 0.71 \\
\hline Comprometer-se a ser fisicamente ativo/ Make a commitment to be physically active on a regular basis & 0.75 & 0.75 \\
\hline Tornar-se fisicamente ativo nas próximas semanas/ Start being physically active in the next few weeks & 0.69 & 0.69 \\
\hline \multicolumn{3}{|l|}{ Preparação/Preparation } \\
\hline Achar o programa de atividade física que você goste/ Find a physical activity program that you would enjoy & 0.71 & 0.71 \\
\hline Achar um lugar adequado para ser fisicamente ativo/ Find a convenient place to be physically active & 0.81 & 0.81 \\
\hline Achar um lugar seguro para ser fisicamente ativo/ Find a safe place to be physically active & 0.41 & 0.41 \\
\hline Achar tempo na sua agenda ocupada para ser fisicamente ativo/ Find time in your busy schedule to be physically active & 0.68 & 0.68 \\
\hline Reorganizar o seu horário semanal para ser fisicamente ativo/ Rearrange your schedule to be physically active & 0.69 & 0.69 \\
\hline Achar um colega para ser fisicamente ativo/ Find a partner to be physically active & 0.25 & -- \\
\hline $\begin{array}{l}\text { Achar formas de ser fisicamente ativo quando o tempo estiver ruim/ Find ways to be physically active when the } \\
\text { weather is bad }\end{array}$ & 0.71 & 0.71 \\
\hline \multicolumn{3}{|l|}{ Manutenção/Ação/Action/Maintenance } \\
\hline $\begin{array}{l}\text { Manter o seu programa de atividade física quando as suas responsabilidades familiares se tornarem mais exigentes que } \\
\text { o normal/ Maintain your physical activity program when your family responsibilities are more demanding than usual }\end{array}$ & 0.71 & 0.71 \\
\hline $\begin{array}{l}\text { Manter o seu programa de atividade física quando as suas responsabilidades no trabalho se tornarem maiores do que } \\
\text { o normal/ Maintain your physical activity program when your work responsibilities are more demanding than usual }\end{array}$ & 0.71 & 0.71 \\
\hline $\begin{array}{l}\text { Manter o seu programa de atividade física durante os períodos de férias/ Maintain your physical activity program } \\
\text { during the holiday season }\end{array}$ & 0.72 & 0.72 \\
\hline $\begin{array}{l}\text { Achar formas de manter o seu programa de atividade física por mais três meses/ Find ways to maintain your } \\
\text { physical activity program for another } 3 \text { months }\end{array}$ & 0.67 & 0.67 \\
\hline $\begin{array}{l}\text { Manter o seu programa de atividade física por mais três meses/ Maintain your physical activity program for } \\
\text { another } 3 \text { months }\end{array}$ & 0.78 & 0.77 \\
\hline \multicolumn{3}{|l|}{ Movimento de recaída/Moving out of relapse } \\
\hline Começar o seu programa de atividade física novamente/ Begin your physical activity program again & 0.74 & 0.74 \\
\hline Comprometer-se em ser fisicamente ativo novamente/ Commit to being physically active again & 0.83 & 0.83 \\
\hline Definir uma rotina para ser fisicamente ativo/ Set a regular routine to be physically active again & 0.81 & 0.82 \\
\hline Sentir-se confortável em ser fisicamente ativo novamente/ Feel comfortable being physically active again & 0.83 & 0.83 \\
\hline \multicolumn{3}{|l|}{ Indexes for factor analysis } \\
\hline Kayser-Meyer-Olkin - KMO & 0.88 & 0.88 \\
\hline Bartlett's sphericity test & 0.001 & 0.001 \\
\hline Explained variance & $50.4 \%$ & $52.7 \%$ \\
\hline
\end{tabular}

Table 2 - Total value and alteration of the total value of Cronbach's alpha with the exclusion of items from the SESBC in 291 administrative technicians from two State Foundations of Santa Catarina.

\begin{tabular}{lc}
\hline In case the item were excluded & $\begin{array}{c}\text { Value of } \\
\text { Cronbach's alpha }\end{array}$ \\
\hline $\begin{array}{l}\text { Ser fisicamente ativo (por exemplo, realizar uma caminhada confortável de } 30 \text { minutos em 1 dia) )/ Be physically active (i.e., accumulate } 30 \\
\text { min of brisk walking in } 1 \text { day) }\end{array}$ & 0.93 \\
Ser fisicamente ativo regulamente (ser ativo 3 a 5 dias por semana) )/ Be physically active on a regular basis (be active 3 to 5 days a week) & 0.93 \\
Comprometer-se a ser fisicamente ativo/ Make a commitment to be physically active on a regular basis & 0.93 \\
Tornar-se fisicamente ativo nas próximas semanas/ Start being physically active in the next few weeks & 0.93 \\
Achar o programa de atividade física que você goste/ Find a physical activity program that you would enjoy & 0.93 \\
Achar um lugar adequado para ser fisicamente ativo/ Find a convenient place to be physically active & 0.93 \\
Achar um lugar seguro para ser fisicamente ativo/ Find a safe place to be physically active & 0.94 \\
Achar tempo na sua agenda ocupada para ser fisicamente ativo/ Find time in your busy schedule to be physically active & 0.93 \\
Reorganizar o seu horário semanal para ser fisicamente ativo/Rearrange your schedule to be physically active & 0.93 \\
Achar formas de ser fisicamente ativo quando o tempo estiver ruim/ Find ways to be physically active when the weather is bad \\
Manter o seu programa de atividade física quando as suas responsabilidades familiares se tornarem mais exigentes que o normal/ Maintain \\
your physical activity program when your family responsibilities are more demanding than usual
\end{tabular}

\section{Continua...}


... continua

In case the item were excluded

Value of

Cronbach's alpha

Manter o seu programa de atividade física quando as suas responsabilidades no trabalho se tornarem maiores do que o normal/ Maintain

0.93

your physical activity program when your work responsibilities are more demanding than usual

Manter o seu programa de atividade física durante os períodos de férias/ Maintain your physical activity program during the holiday season 0.93

Achar formas de manter o seu programa de atividade física por mais três meses/ Find ways to maintain your physical activity program for

0.93

another 3 months

Manter o seu programa de atividade física por mais três meses/ Maintain your physical activity program for another 3 months

0.93

Começar o seu programa de atividade física novamente/ Begin your physical activity program again

0.93

Comprometer-se em ser fisicamente ativo novamente/ Commit to being physically active again

0.93

Definir uma rotina para ser fisicamente ativo/ Set a regular routine to be physically active again

0.93

Sentir-se confortável em ser fisicamente ativo novamente/ Feel comfortable being physically active again

0.93

All $(\mathrm{n}=19$ items $)$

0.94

Table 3 - Reproducibility of the SESBC according to test and retest in 91 university students of Florianópolis.

\begin{tabular}{|c|c|c|c|c|}
\hline Items & $\begin{array}{l}\text { Administration } 1 \\
\text { Mean (SD) }\end{array}$ & $\begin{array}{l}\text { Administration } 2 \\
\text { Mean (SD) }\end{array}$ & $\mathrm{ICC}$ & $95 \% \mathrm{CI}$ \\
\hline $\begin{array}{l}\text { Ser fisicamente ativo (por exemplo, realizar uma caminhada confortável } \\
\text { de } 30 \text { minutos em } 1 \text { dia) / Be physically active (i.e., accumulate } 30 \text { min of } \\
\text { brisk walking in } 1 \text { day) }\end{array}$ & $1.58(0.95)$ & $1.51(0.85)$ & 0.41 & $0.10-0.61$ \\
\hline $\begin{array}{l}\text { Ser fisicamente ativo regulamente (ser ativo } 3 \text { a } 5 \text { dias por semana) )/ Be } \\
\text { physically active on a regular basis (be active } 3 \text { to } 5 \text { days a week) }\end{array}$ & $1.66(0.85)$ & $1.65(0.94)$ & 0.67 & $0.27-0.84$ \\
\hline $\begin{array}{l}\text { Comprometer-se a ser fisicamente ativo/ Make a commitment to be } \\
\text { physically active on a regular basis }\end{array}$ & $1.89(1.09)$ & $1.82(1.06)$ & 0.71 & $0.27-0.94$ \\
\hline $\begin{array}{l}\text { Tornar-se fisicamente ativo nas próximas semanas/ Start being physically } \\
\text { active in the next few weeks }\end{array}$ & $1.92(1.10)$ & $1.82(1.06)$ & 0.66 & $0.27-0.74$ \\
\hline $\begin{array}{l}\text { Achar o programa de atividade física que você goste/ Find a physical } \\
\text { activity program that you would enjoy }\end{array}$ & $1.60(0.77)$ & $1.71(0.80)$ & 0.67 & $0.27-0.84$ \\
\hline $\begin{array}{l}\text { Achar um lugar adequado para ser fisicamente ativo/ Find a convenient } \\
\text { place to be physically active }\end{array}$ & $2.00(1.00)$ & $1.90(0.95)$ & 0.80 & $0.17-0.94$ \\
\hline $\begin{array}{l}\text { Achar um lugar seguro para ser fisicamente ativo/ Find a safe place to be } \\
\text { physically active }\end{array}$ & $1.99(1.05)$ & $2.15(1.40)$ & 0.58 & $0.10-0.74$ \\
\hline $\begin{array}{l}\text { Achar tempo na sua agenda ocupada para ser fisicamente ativo/ Find } \\
\text { time in your busy schedule to be physically active }\end{array}$ & $2.62(1.35)$ & $2.55(1.21)$ & 0.68 & $0.20-0.89$ \\
\hline $\begin{array}{l}\text { Reorganizar o seu horário semanal para ser fisicamente ativo/ Rearrange } \\
\text { your schedule to be physically active }\end{array}$ & $2.49(1.25)$ & $3.02(1.19)$ & 0.70 & $0.21-0.90$ \\
\hline $\begin{array}{l}\text { Achar formas de ser fisicamente ativo quando o tempo estiver ruim/ Find } \\
\text { ways to be physically active when the weather is bad }\end{array}$ & $3.02(1.19)$ & $2.43(1.09)$ & 0.68 & $0.20-0.78$ \\
\hline $\begin{array}{l}\text { Manter o seu programa de atividade física quando as suas } \\
\text { responsabilidades familiares se tornarem mais exigentes que o } \\
\text { normal/ Maintain your physical activity program when your family } \\
\text { responsibilities are more demanding than usual }\end{array}$ & $1.58(0.95)$ & $2.03(0.98)$ & 0.68 & $0.27-0.90$ \\
\hline $\begin{array}{l}\text { Manter o seu programa de atividade física quando as suas } \\
\text { responsabilidades no trabalho se tornarem maiores do que o normal/ } \\
\text { Maintain your physical activity program when your work responsibilities } \\
\text { are more demanding than usual }\end{array}$ & $1.66(0.85)$ & $1.93(0.99)$ & 0.66 & $0.18-0.80$ \\
\hline $\begin{array}{l}\text { Manter o seu programa de atividade física durante os períodos de férias/ } \\
\text { Maintain your physical activity program during the holiday season }\end{array}$ & $1.89(1.09)$ & $2.72(1.05)$ & 0.62 & $0.20-0.80$ \\
\hline $\begin{array}{l}\text { Achar formas de manter o seu programa de atividade física por mais três meses/ } \\
\text { Find ways to maintain your physical activity program for another } 3 \text { months }\end{array}$ & $1.92(1.10)$ & $2.73(1.20)$ & 0.73 & $0.24-0.94$ \\
\hline $\begin{array}{l}\text { Manter o seu programa de atividade física por mais três meses/ Maintain } \\
\text { your physical activity program for another } 3 \text { months }\end{array}$ & $1.60(0.77)$ & $1.92(0.10)$ & 0.66 & $0.30-0.87$ \\
\hline $\begin{array}{l}\text { Começar o seu programa de atividade física novamente/ Begin your } \\
\text { physical activity program again }\end{array}$ & $2.00(1.00)$ & $2.03(0.98)$ & 0.77 & $0.23-0.92$ \\
\hline $\begin{array}{l}\text { Comprometer-se em ser fisicamente ativo novamente/ Commit to being } \\
\text { physically active again }\end{array}$ & $1.99(1.05)$ & $2.02(0.98)$ & 0.77 & $0.27-0.94$ \\
\hline $\begin{array}{l}\text { Definir uma rotina para ser fisicamente ativo/ Set a regular routine to be } \\
\text { physically active again }\end{array}$ & $2.62(1.35)$ & $2.10(1.02)$ & 0.77 & $0.22-0.91$ \\
\hline $\begin{array}{l}\text { Sentir-se confortável em ser fisicamente ativo novamente/ Feel } \\
\text { comfortable being physically active again }\end{array}$ & $2.49(1.25)$ & $1.95(0.95)$ & 0.41 & $0.16-0.79$ \\
\hline
\end{tabular}


of terms and expressions that could be used without changing the items' context. When compared to the original scale, the back-translation revealed slight discrepancies resulting from adjustments that had been made to cope with specificities of items eleven and twelve: the term "usual" was replaced by "normal".

In the cross-cultural adaptation, analyzing semantic and conceptual equivalence, it was shown that the translation of the SESBC was easy. Conceptual equivalence is an important stage in cross-cultural adaptation ${ }^{17}$ and revealed a low index of corrections and adjustments. In psychometric studies, it is fundamental to look after information quality, as there is a connection between the theoretical content and the reality of the population ${ }^{16}$.

The results obtained in the validation process of the SESBC showed that the items referring to self-efficacy assessment have validity in Brazil, when the scale was assessed by administrative technicians from the state of Santa Catarina. Of the 20 items that were part of the original scale, 19 presented a factor loading higher than 0.30 . The item "find a partner to be physically active" was excluded because it presented a factor loading lower than 0.30 . The low factor loading found in the above-mentioned item can be explained by the fact that this item presents a weak linear relationship to the investigated construct. Concerning dimensionality, the SESBC items loaded in a unidimensional way, confirming the initial proposal for this instrument ${ }^{10}$. Unfortunately, we did not find any study that assessed the dimensionality proposed in the SESBC, which prevented us from comparing the findings of our study. However, we suggest that further investigations should be conducted to assess the validity of the SESBC in samples with other sociocultural characteristics.

The SESBC achieved adequate values for Cronbach's alpha, confirming the scale's high internal consistency found in the original study $(\alpha=0.96)^{10}$. The non-alteration in the total value of Cronbach's alpha with the exclusion of any item of the scale suggested that all the 19 items of the scale were important in its total composition.

All the scale's items presented an adequate reproducibility. In addition, the means of the scores obtained in the first and second administrations do not present significant differences, which shows that the scale's items, like the instrument in general, presented satisfactory levels of reproducibility ${ }^{17}$. These results corroborate the findings of the original study ${ }^{10}$.

One of the study's positive points that deserves attention is the assessment of the psychometric properties of a new instrument to measure self-efficacy in the context of physical activity in Brazil, as we have not identified another specific instrument that assesses self-efficacy characteristics for the stages of behavior changes related to physical activity. As for the study's negative points, we highlight the specificity of the sample, which does not allow the generalization of the results to the entire Brazilian population, being limited to workers and university students from the South of Brazil.

The version in Portuguese of the SESBC achieved adequate values for construct validity, internal consistency and reproducibility, and it could be administered to measure self-efficacy for physical activity practice among civil workers and university students from the South region of Brazil. It is important to mention that, although the scale was developed for the North American population, the findings confirm it is valid and reliable to be employed in the assessed sample.

\section{Conflicts of interest}

The authors declare no conflicts of interest.

\section{Authors' contribution}

Silva WR, participated in the initial conception of the study, in data analysis and in the writing and critical review of the text. Sacomori $\mathrm{C}$, participated in data collection and analysis. Medeiros T, participated in the initial conception of the study and in the critical review of the text. Lisboa T, participated in the writing and critical review of the text. Freitas KTD, participated in the critical review of the text. Cardoso FL, participated in the initial conception of the study and in the writing and critical review of the text.

\section{References}

1. Bandura A, Azzi RG, Polydoro S. Teoria Social Cognitiva: conceitos básicos. Porto Alegre: Artmed, 2008.

2. Prochaska JO, DiClemente CC. Toward a comprehensive model of change. In Treating addictive behaviors. Springer US, 1986.

3. Maiman LA, Becker MH. The Health Belief Model: Origins and correlates in psychological theory. Health Educ Monogr. 1974;(2):336-53.

4. Ajzen I. The theory of planned behavior. Organ Behav Hum Decis Process. 1991;50(2):179-211.

5. Olander EK, Fletcher H, Williams S, Atkinson L, Turner A, French DP. What are the most effective techniques in changing obese individuals' physical activity self-efficacy and behaviour: a systematic review and meta-analysis. Int J Behav Nutr Phys Act. 2013;10(1):01-15.

6. Resnick B, Jenkins LS. Reliability and validity of the selfefficacy for exercise scale. Nurs Res. 2000;26(2):11-7.

7. Barder FD. Effects of social support on physical activity, selfefficacy, and quality of life in adult cancer survivors and their Caregivers. Oncol Nurs Forum. 2013;40(5):481-9. 
8. Cabrera TF, Anzeno MA, Sanchez IMH, Méndez SR, Olmo AFD. Construcción y validación de una escala de autoeficacia para la actividad física. Rev Esp Salud Publica. 2011;85(4):405-17.

9. Rydwik E, Hovmoller F, Bostrom C. Aspects of reliability and validity of the Swedish version of the Self-Efficacy for Exercise Scale for older people. Physiother Theory Pract. 2013;30(2):131-7.

10. Mâsse LC, Heesch KC, Eason KE, Wilson M. Evaluating the properties of a stage-specific self-efficacy scale for physical activity using classical test theory, confirmatory factor analysis and item response modeling. Health Educ Rese. 2006;21(1):33-46.

11. Laffrey SC, Wannipa A. Development of an exercise selfefficacy questionnaire for older Mexican American women. J Nurs Meas. 2001;1(3):259-73.

12. Silva WR, Ferrari EP, Medeiros TE, Freitas KTD, Tkac CM, Cardoso FL. Athletic Identity Measurement Scale: Translation, Adaptation and Validation for Brazil. Motriz. 2016;22(1):42-7.

13. Hutchinson $A D, W$ ilson $C$. Improving nutrition and physical activity in the workplace: a meta-analysis of intervention studies. Health Promot Int. 2012;27(2):238-49.
14. Guillemin F, Bombardier C, Beaton D. Cross-cultural adaptation of health-related quality of life measures: Literature review and proposed guidelines. J Clin Epidemiol. 1993;46(12):1417-32.

15. Alexandre NMC, Guirardello EDB. Adaptación cultural de instrumentos utilizados en salud ocupacional. Rev Panam Salud Publica. 2002;11(2):109-11.

16. Pasquali L. Instrumentos psicológicos: Manual prático de elaboração. Brasília: LabPAM, 1999.

17. Fleiss J. Statistical methods for rates and proportions. New York: John Wiley \& Sons, 1981.

18. Rech CR, Sarabia TT, Fermino RC, Hallal PC, Reis RC. Propriedades psicométricas de uma escala de autoeficácia para a prática de atividade física em adultos brasileiros. Rev Panam Salud Publica. 2011;29(4):59-67.

19. Silva J, Silva K. Estágios de mudança de comportamento para atividade física em adolescentes: revisão sistemática. Rev Bras Ativ Fís Saúde. 2015;20(3):214-31.

Received: 17/09/2017

Accepted: 07/06/2018

\section{Quote this article as:}

Silva WR, Sacomori C, Medeiros TE, Lisboa T, Freitas KTD, Cardoso FL. Adaptation and validation of a Self-Effcacy Scale for Physical Activity Practice - SESBC Scale. Rev Bras Ativ Fís Saúde. 2018;23:e0038. DOI: 10.12820/rbafs.23e0038 